Historic, Archive Document

Do not assume content reflects current scientific knowledge, policies, or practices. 



\section{FOREST NURSERY CO.}

\author{
ESTARLISHED 1857 \\ แ J. Н. Н. Вичг \\ INCORTURATHD I 195
}

CAPITAL SIOLK, $\$ 75,000,00$
Groners and Wholesale Dealers

\section{Forest and Shade Trees. Omamental Shrubs Evergreens and Roses}

\section{re}

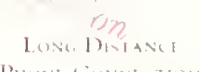

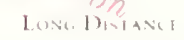

P'HONI CONATHONO

\section{$\because$}

Federal Horticultura I Bdgedinnville, TENN.

D. Lums den.

iasington, D, C.

We exercise the greatesit care to keen true to name and hold ourselves in readiness at all times to replaces on

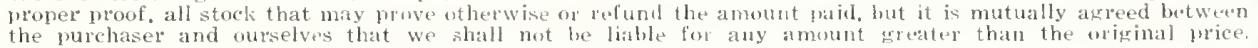

February 1928 .

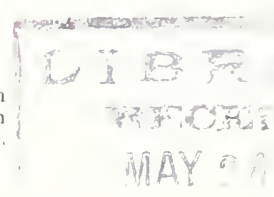

Dear Eriend:-

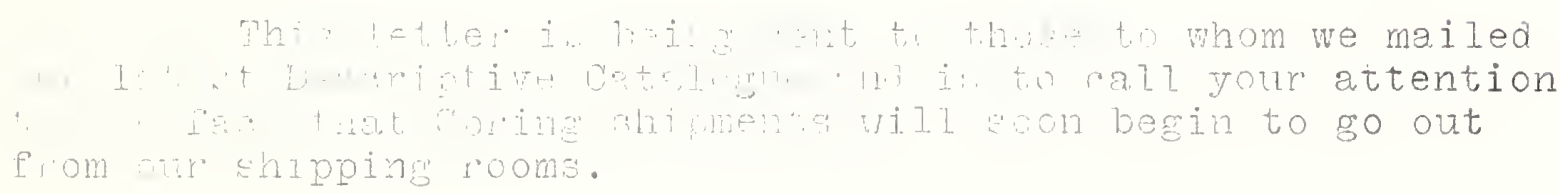

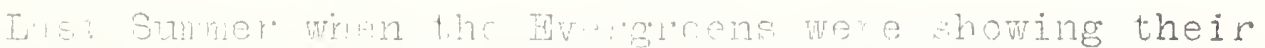

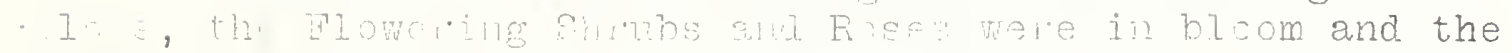

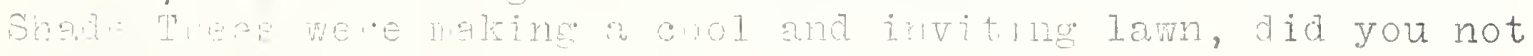

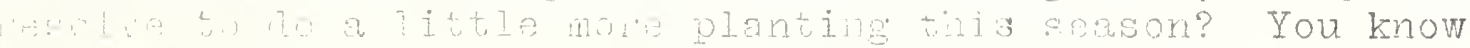

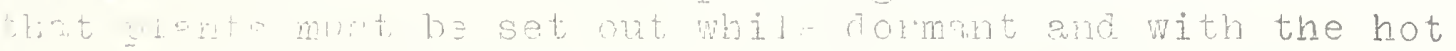

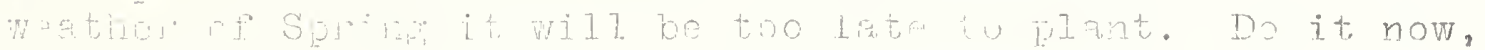

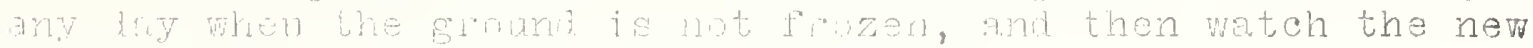

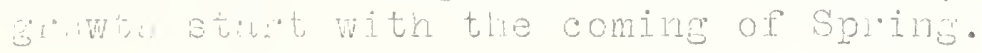

Wh not look throuph on Cutalogne and tell us what

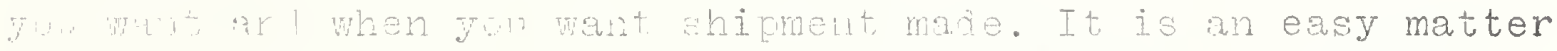

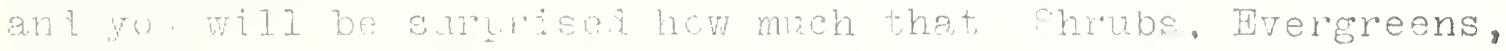
Thow Roser, Vines etc. will ad to yolr pioperty both in looks ant money value.

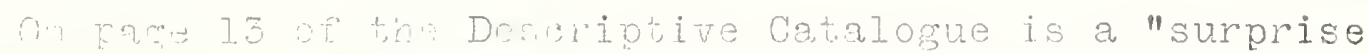

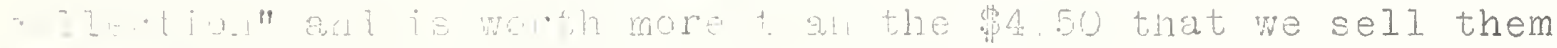
f.l, b t me wat you to set a quainter with the stock. We are Hestad to mals hipment of uhes collections now. Send us a huch for this mout anl teld ue to male shipment. We want ron to not a the root wy tem an the well leveloped plants when they arrive.

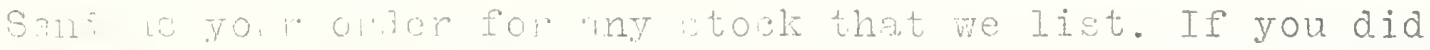

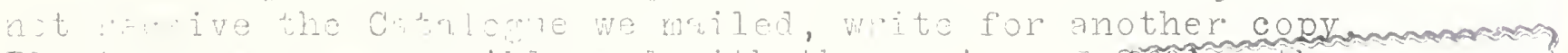

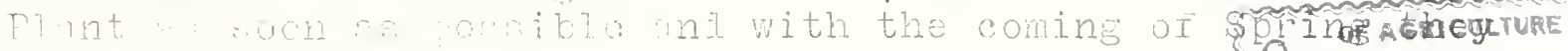

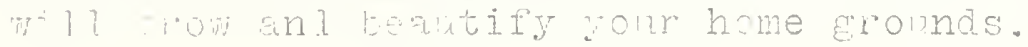

Sircerely youra,

FE RET LURERY CURPAIY

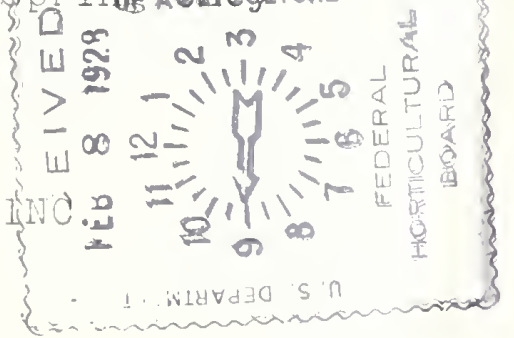




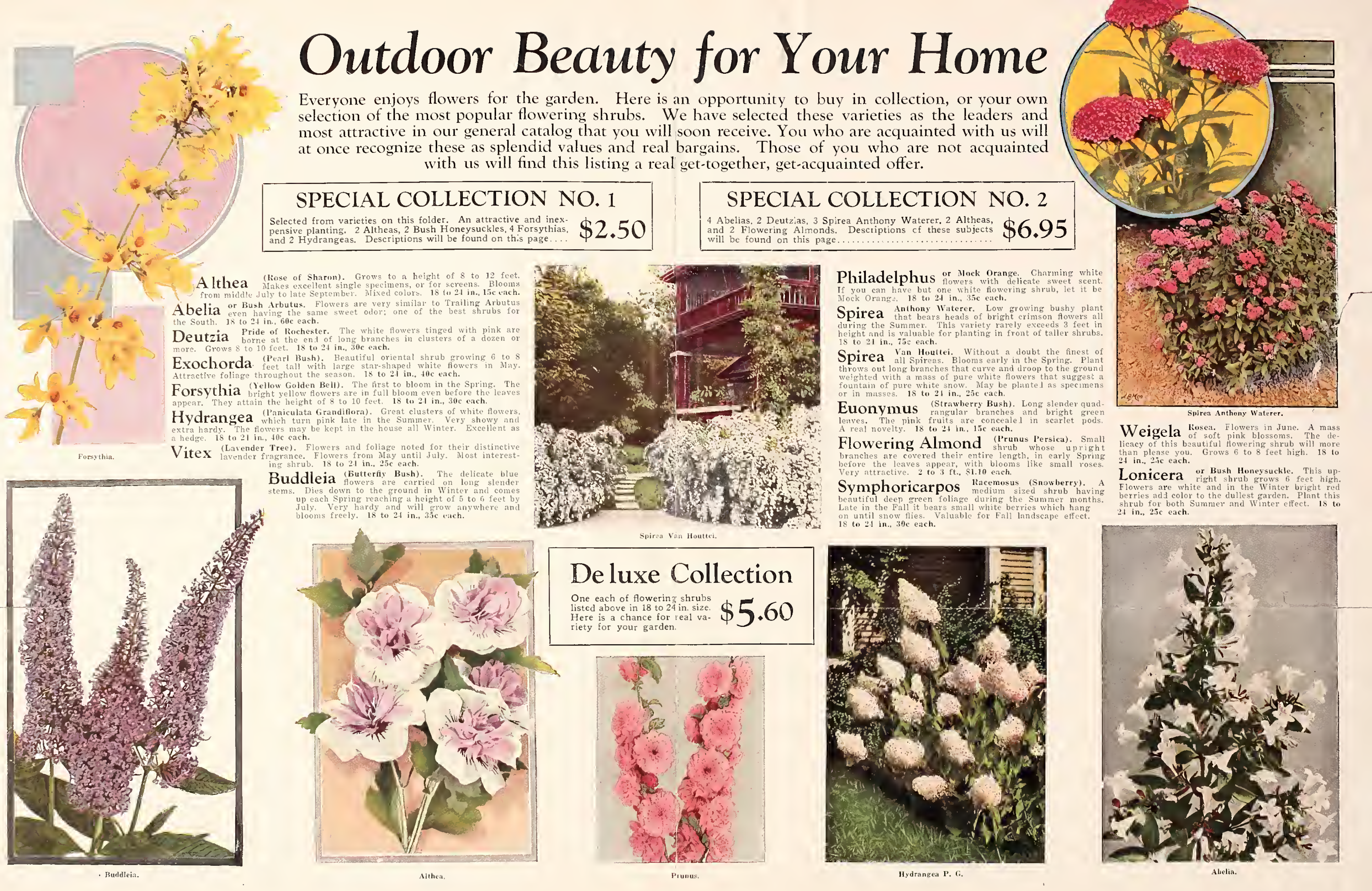





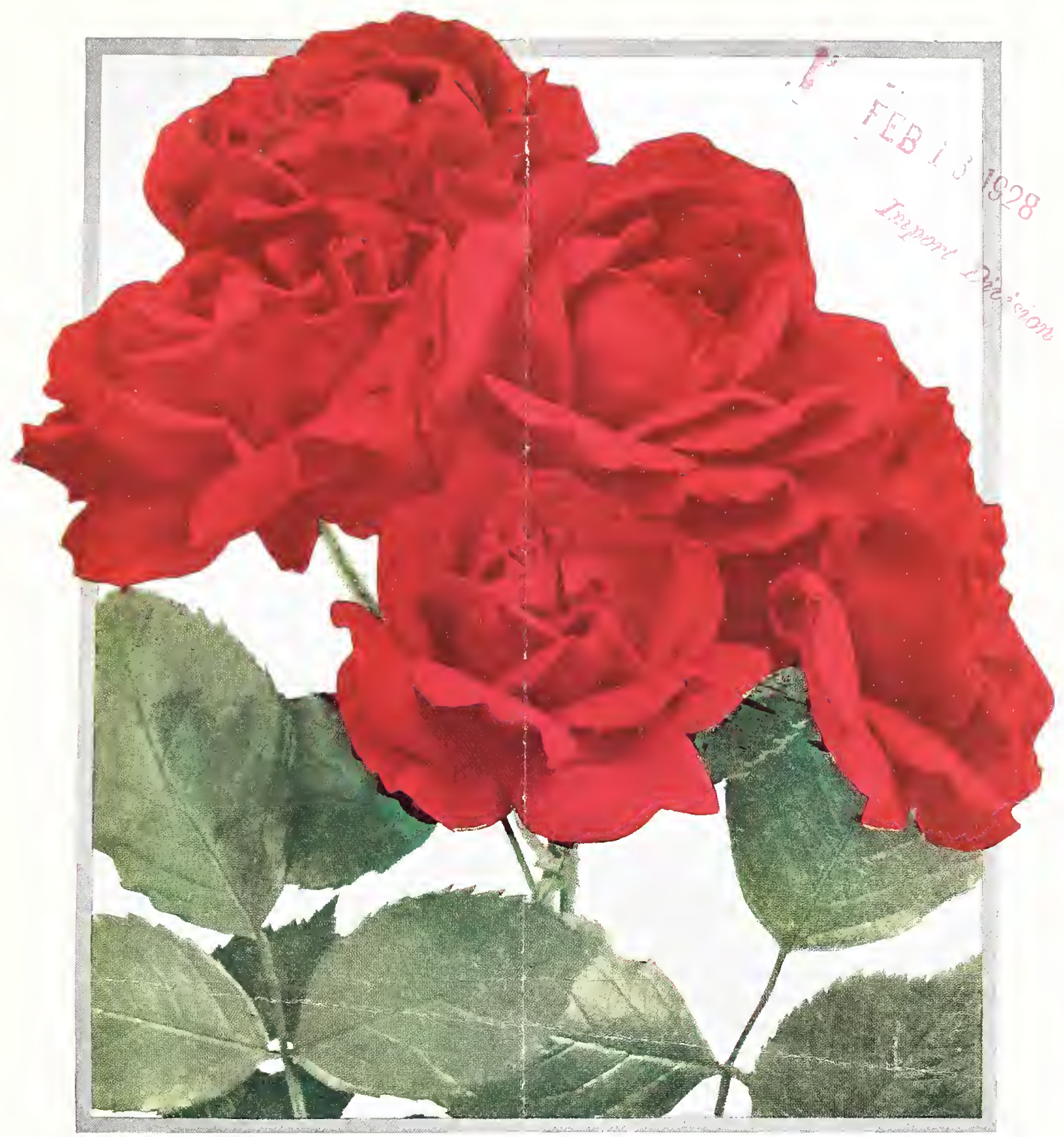

\section{PAUL'S SCARLET CLIMBER}

7 HIS is the most intensely red of all Climbing Roses, with flowers of vivid searlet whieh do not fade in the hot sun. The individual flowers are mueh larger than those of the old-fashioned ramblers and are produeed profusely and continuously for almost four weeks in June and July.

The plant is very vigorous but does not grow so tall as to beeome unmanageable. It may be trained to a poreh pillar, on a trellis, or kept tied to a post 6 to 10 feet high, whieh it will elothe with a flaming mantle of flowers every year, attraeting the attention of everybody by its superlative brillianee and beauty.

Paul's Searlet Climber is rated by the Ameriean Rose Soeiety as one of the finest climbers in the United States.

\section{Forest Nursery Company}

R.R.No.2, Box 66

McMINNVILLE, TENNESSEE 


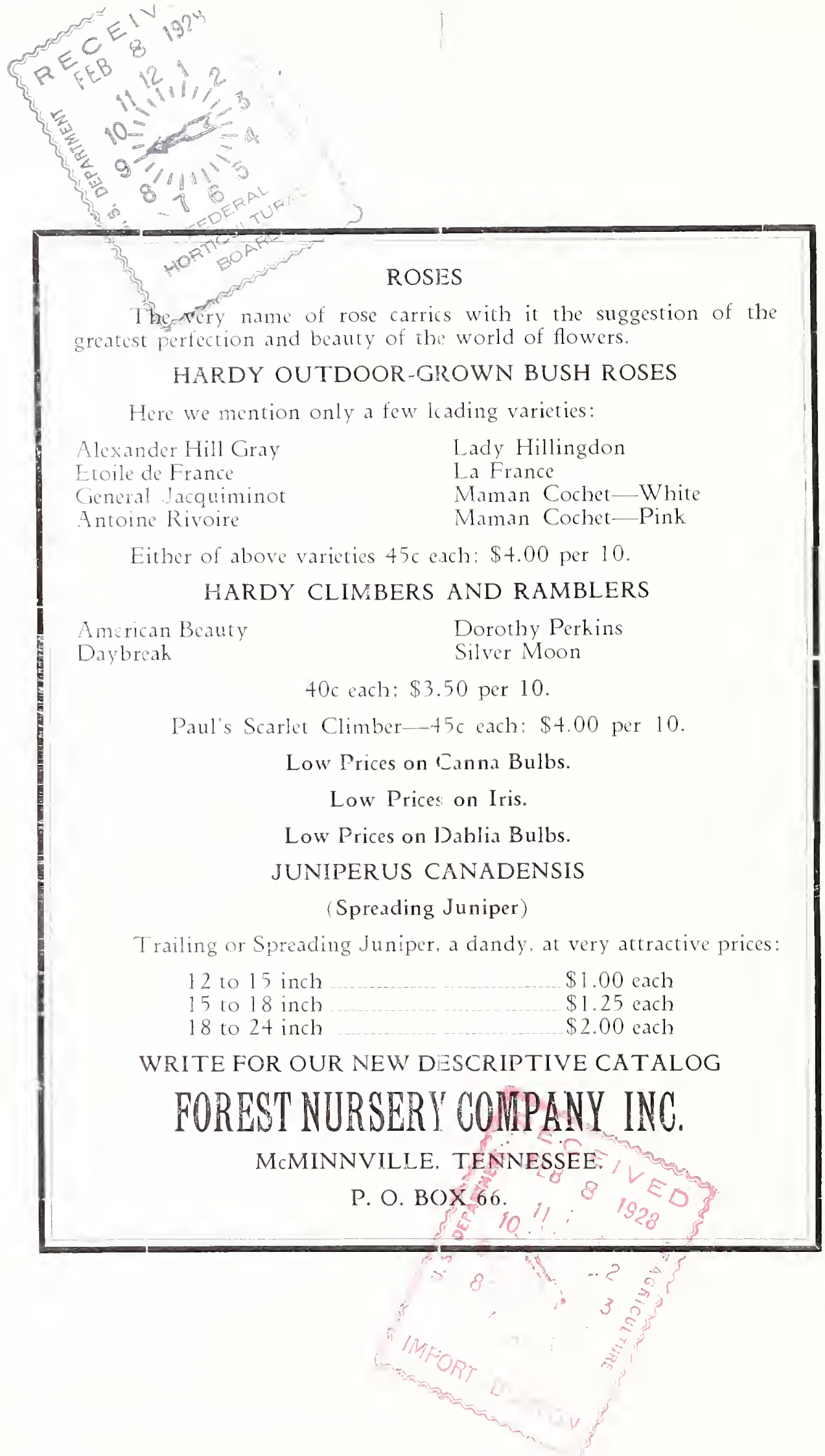


(2)

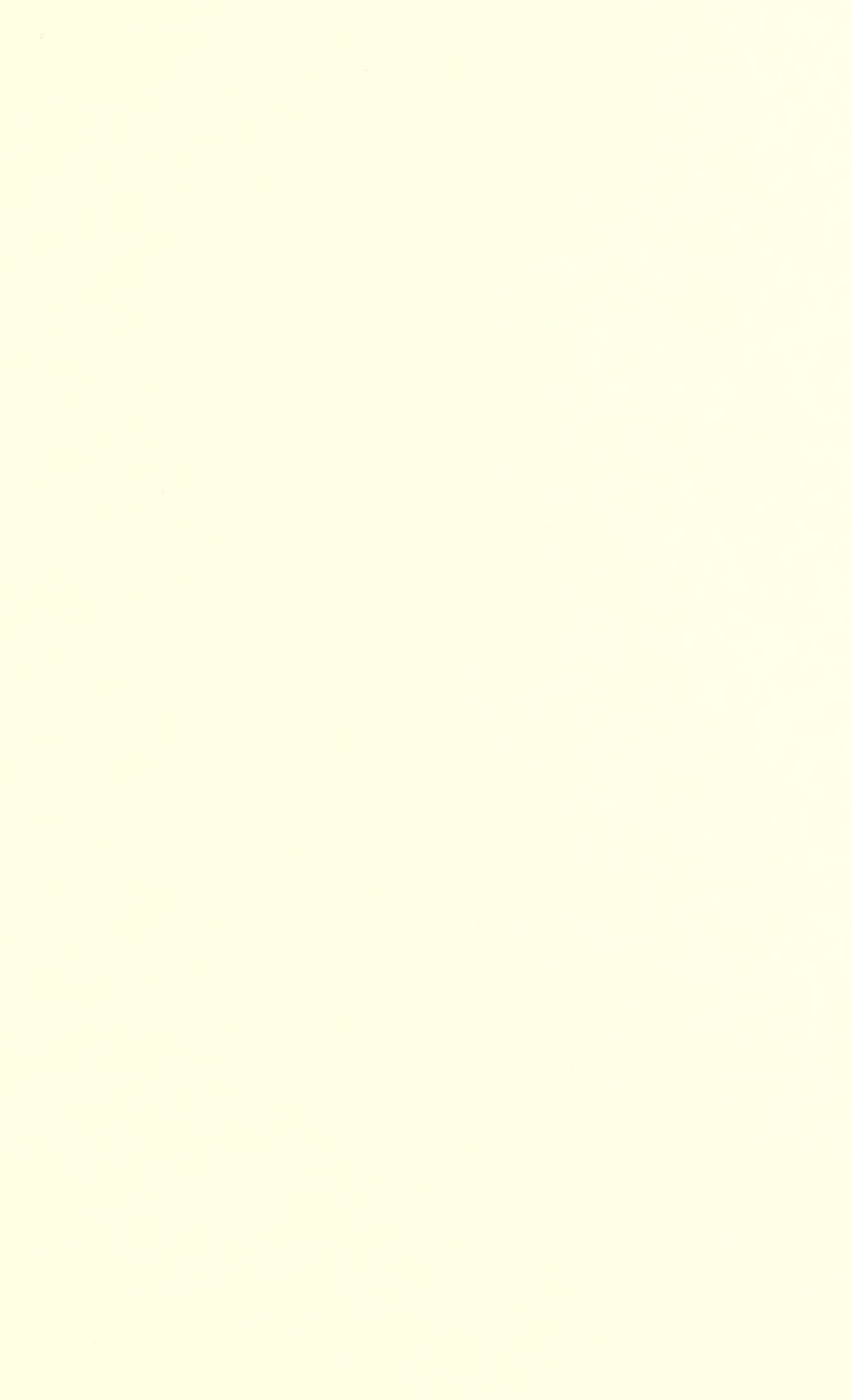




\section{BARBERRY-The Hedge Everlasting}

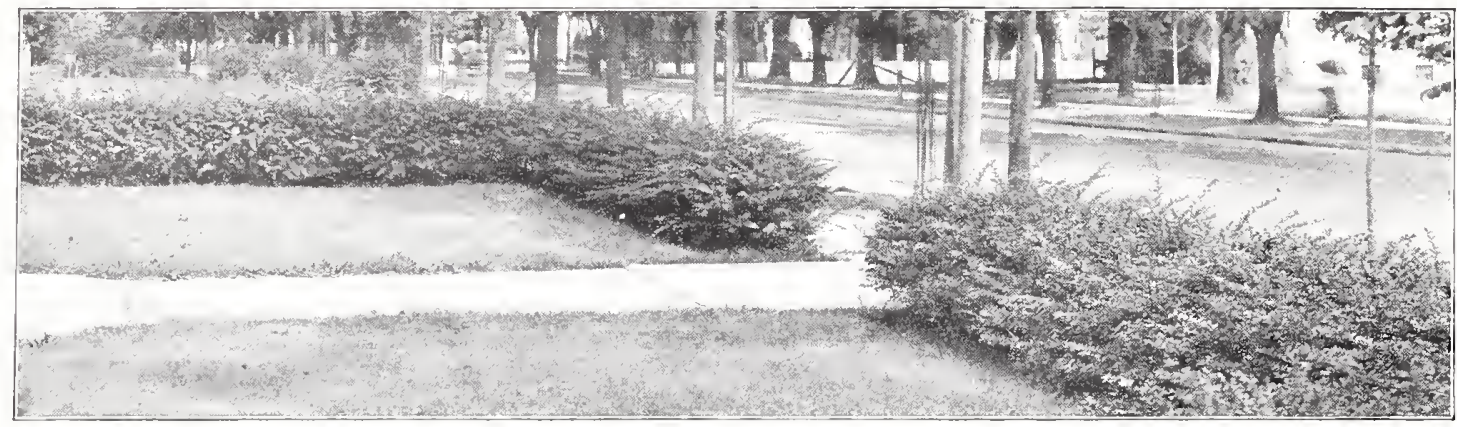

"What's the best plant for a hedge in the South?"--we have been asked this question many times. Often we want to know something about the soil and where the hedge is to be planted. But about seven times out of ten we can answer right quick "Japanese Barberry"- and be sure the answer is right, too.

\section{Japanese Barberry Makes the Most Beautiful Hedge}

Finm Christmas to Christmas-every day in the year-Parberry is beautiful. In early Spring the new leares are a soft shade of oreen: then as Summer comen they turn to deep glossy oreen: later on they assume shade w crimson, and brown and bronze-green. and keep these colors until the old leaves are pushed off the next spring. To give still more color, the long branches carry a multitude of scarlet herries, which will give frud to the birds during the cold weather.

Japanese Barberry Makes the Best Hedge

In almost every place, Jamanese Barberry makes the best hedlue yous can have. The plants spread out, with long, dromping branche that cross up and down and sideways into a conpact mass. Thene branches are covered with short, stiff spines, like little needles. The growth of the plants, with these spinen, mikes a barrier that will keep out dogs and cats, and a husky hoy inn"t likely to jump, through w over the hedge the second time. lirrherry in better than boarde to bar out trenpaners.

\section{Japanese Barberry is an Economical Hedge}

The first cont ir the only cost. You don't have to put on new slats, as on a board fence, yon don't have to string new wires or tighten 11 old ones: theres no painting or whitewashing. with its mensiness and cost. Naybe once a year you will want to clipe the ends of the long branches to keep them in bunds and to make the plante sond ont more branches thus givine I still tighter and hedter herlge.

\section{Where to Use Japanese Barberry}

Barleery can be nsed in many places. First, as a boundary hedge between your srounds and your neighbor's. Second, along the itreet line, or on both sides of the walk from the stree to the house, and aromel the foundation to hide the walls or billars-fine here, for it never gets high enough to darken the windows. Third, use Barberry in large groups at the lot corncrs, or at curves in the drive.

\section{How Much Barberry Will You Need}

For a single-row hedge, set the plants a foot apart-a hundred feet of hedge needs a hundred plants. For a double hedge, "stagger" the blants, 9 inches between the rows, and 15 inches between plants-a hundred feet of hedge needs about 160 plants. An'mund the house set at least two rows, in "staggered" fashion. about 15 inches apart each way. Groups at the lot corners and along driveways can le figured in the same way.

\section{Japanese Barberry Plants Are Low. Priced}

1 leres gond news. We grow Japanese Barberry in enormous yuantities - fields of it. So much that we can't count all the plants-we connt the plants in me row, then the rows, and estmate the total quantity. Usually the estimate is too low, and we have more plant than we thought-so you get the hencfit, and here is the nice-

12 to 18 inches

18 to 24 inche.

24 to, 3i) inchen. $\begin{array}{crr}\text { Each Per } 10 & \text { Per } 106 \\ \$ \$ 0.25 & \$ 2.00 & \$ 12.50 \\ 3.50 & 2000\end{array}$

H(1.,(1)

\section{Privet Hedges are Valuable in Certain Places}

Varieties of l'rivet can be uned in much the same way as Barberry, but F'rivet must be pruned regularly to get the best appearance. We grow four varieticis.

Amur River North

12 tu 18 incher.

18 to 24 inches, brincherl

2 to 3 feet, branched........

Amur River South

18 to 24 inches, 1 -yr., seedlings.

18 to $2+$ inches, 2-vr, liranched

2 tw 3 feet, 2-yr., branched.

3 to 4 feet, $2-y 1$., branched heavy.

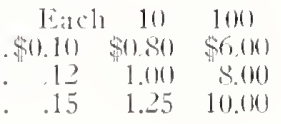

$.08 \quad .50 \quad 4.00$

$.10 \quad .80 \quad 6 .(10)$

$\begin{array}{lll}12 & 1.00 & 7.50\end{array}$

\section{California}

12 tur 18 inches, branched

Is to 24 inches, branched.

2 to 3 feet, branched.

Ibota

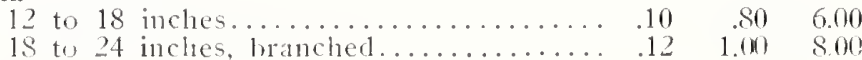

2 to 3 feet, branched ................. 15 1.25 10.00 